\title{
Association of Procalcitonin Values with Mortality of Elderly Sepsis Patients
}

\author{
Anita Rosari Dalimunthe ${ }^{1}$, I Dewa Putu Pramantara ${ }^{2}$, Probo Suseno ${ }^{2}$ \\ ${ }^{1}$ Division of Geriatric, Department of Internal Medicine, RSUP Haji Adam Malik, Medan, Indonesia \\ ${ }^{2}$ Division of Geriatric, Department of Internal Medicine, Faculty of Medicine, Public Health and Nursing, \\ Universitas Gadjah Mada/RSUP Dr. Sardjito Yogyakarta \\ Corresponding Author: Anita Rosari Dalimunthe
}

DOI: https://doi.org/10.52403/ijrr.20220204

\begin{abstract}
Background: Elderly is an age group that is prone to sepsis and is sometimes difficult to enforce because signs of inflammation rarely appear. Procalcitonin is a specific marker for bacterial infection in the elderly and can be a sign of the severity of sepsis and can be used as a predictor of septic death in the elderly. The purpose of this study was to determine the relationship between procalcitonin levels and mortality in elderly septic patients.
\end{abstract}

Methods: This study was an analytic observational study with a retrospective cohort design. Data were obtained from the patient's medical records. To analyze the sensitivity and specificity of procalcitonin values in sepsis patients, statistical analysis of receiver-operating characteristics (ROC) curves was used with significant results if the ROC curve value was more than $50 \%$. To determine the procalcitonin value with outcome, Chi-square test was performed. The data was processed with SPSS version 22.0. The test results are said to be meaningful if the $\mathrm{p}$ value $<0.05$.

Results: The subjects of this study amounted to 52 people who met the inclusion and exclusion criteria. The median value of the age of the subjects was $66(60-87)$ years with the most male subjects $51.92 \%$. The diagnosis of severe sepsis was $48.08 \%$ followed by $29.62 \%$ sepsis and $25 \%$ septic shock. Subjects died as many as 27 subjects (51.92\%). Hemoglobin level 11.3 $\mathrm{g} / \mathrm{dl}$; leukocytes $15.26 .103 / \mathrm{ml}$; platelets $150.103 / \mathrm{ml}$ and the value of procalcitonin 12.42 $\mathrm{mcg} / \mathrm{dl}$. The procalcitonin ROC curve showed that procalcitonin had a good predictor value (AUC 79.7\%; p value 0.001), the procalcitonin value was $12.67 \mathrm{mcg} / \mathrm{dl}$. Procalcitonin levels $>12.67 \mathrm{mcg} / \mathrm{dl}$ died in $12(75 \%)$ patients while elderly patients with procalcitonin levels $<12.67$ $\mathrm{mcg} / \mathrm{dl}$ died in $6(25 \%)$ patients. The chi-square test got a $p$ value of 0.001 (RR 3 CI 95\% 1.4536.196).

Conclusion: Procalcitonin is associated with mortality in elderly septic patients

Keywords: Procalcitonin, Sepsis, elderly

\section{INTRODUCTION}

Sepsis is an emergency condition that often occurs in the community and requires prompt management. This happens because of a systemic inflammatory response syndrome disorder that causes a decrease in organ function and can fall into a state of shock and death. ${ }^{[1,2]}$ Sepsis is one of the top ten causes of death in the United States. Cases of severe sepsis in the United States are estimated at 751,000 cases every year with a mortality rate of $28.6 \% .^{[3]}$ Inpatients at RSUD Dr. Moewardi in 2009 as many as 28,385 people with a total of 2,288 people who died or $8.06 \%$ of the total hospitalized patients. ${ }^{[4]}$

The elderly is an age group that is prone to sepsis. This condition is caused by comorbid comorbidities, decreased immunity, functional limitations and all things related to age, causing the elderly to be susceptible to sepsis and also increasing mortality. ${ }^{[5]}$ Lemay et al in their study found an increase in the mortality rate of sepsis in patients aged over 65 years as much as 2 
times and aged over 75 years as much as 3 times. ${ }^{[6]}$

Delay in the diagnosis and treatment of sepsis often leads to rapid progression to circulatory collapse, multiple organ failure and death. Therefore, accurate and rapid diagnosis will reduce morbidity, lower healthcare costs, and improve clinical outcomes. Diagnosis of sepsis is difficult, because clinical signs often overlap with non-infectious causes of systemic inflammation. These signs include tachycardia, leukocytosis, tachypnea, and fever, which are collectively termed the Systemic Inflammatory Response Syndromes (SIRS). SIRS is common in critically ill patients, but is also seen in conditions such as trauma, surgery, and hypoxic injuries. In the elderly, the diagnosis of sepsis is sometimes difficult to enforce because signs of inflammation rarely appear, such as fever, tachycardia, tachypnea and in the laboratory there is also an increase in leukocytes so that more sophisticated examinations are needed in addition to paying attention to the clinical course. $^{[7]}$

Blood culture is the gold standard for the diagnosis of sepsis. However, test results are often not available for up to 1248 hours. This highlights the need for the development and evaluation of rapid molecular and biochemical assays for markers of sepsis. In addition, blood cultures can also give false positive results due to organisms that are skin contaminants. Patients who present with fever and positive blood cultures due to contaminant organisms will undergo diagnostic tests, hospitalization, and receive unnecessary antibiotic therapy. ${ }^{[8]}$

Procalcitonin is a specific marker for bacterial infection. Procalcitonin is produced in response to endotoxins or mediators released during bacterial infection (interleukin/IL-1b, tumor necrosis factor (TNF)-a, and IL-6) and is strongly associated with the extent and severity of infection. ${ }^{[9]}$ Procalcitonin can be performed in less than 1 hour and is useful in the emergency department setting in recognizing patients with bacteremia and sepsis. ${ }^{[8]}$ The limitations of procalcitonin in the diagnosis of sepsis include false positive values in severe stressful situations, such as severe injury, surgery, and cardiogenic shock, false negative values at the time of initial infection or local infection, and the cost of the examination is still quite expensive. Many previous studies have been carried out, and procalcitonin has been proposed as a diagnostic marker and included in the definition of sepsis. However, several recent studies have shown different results. ${ }^{[7]}$

Procalcitonin can also be a sign of worsening sepsis that occurs in patients. Djitmau in his research conducted at RSUP Dr. Sardjito got the result that procalcitonin levels will increase according to the severity of sepsis. ${ }^{[10]}$ Procalcitonin increases with the severity of sepsis so that procalcitonin can also be used as a predictor of septic mortality in the elderly.

\section{MATERIAL AND METHODS}

This study is an analytic observational study with a retrospective cohort design to determine the prediction of mortality in elderly patients with a diagnosis of sepsis using procalcitonin values. The data were obtained from the medical records of patients who were treated in the internal medicine ward of RSUP Dr. Sardjito Yogyakarta in 2016. Measurement of procalcitonin was carried out once, namely when the patient was diagnosed with sepsis for the first time, followed by when he was admitted to the ward and the patient was assessed after being treated for the outcome of the disease, namely dead or alive. The research was conducted at the medical record installation of Dr. Sardjito Yogyakarta.

The subjects of the study were patients with clinical sepsis who were first recognized when they first visited the ER who met the inclusion and exclusion criteria. The inclusion criteria for the study were all patients, both male and female, 
aged 60 years or older who were treated at RSUP Dr. Sardjito Yogyakarta with a diagnosis of sepsis. Exclusion criteria for the study were patients suffering from malignancy, chronic infection/inflammation (TB, RA), AIDS, cardiogenic shock, acute pancreatitis, burns, and injuries due to accidents, patients undergoing major surgery, and patients receiving therapy, glucocorticoids, cytostatics, or other immunosuppressant therapy prior to hospital admission.

\section{STATISTICAL METHODS}

To analyze the sensitivity and specificity of procalcitonin values in sepsis patients, statistical analysis of receiveroperating characteristics (ROC) curves was used with significant results if the ROC curve value was more than $50 \%$. The next analysis will determine the cut-off point by considering the sensitivity and specificity of procalcitonin. The resulting cut-off point will be cross-tabulated with the outcome of sepsis, i.e. dead or alive. The data was processed with SPSS version 22.0. The test results are said to be meaningful if the $p$ value $<0.05$.

\section{RESULTS}

\begin{tabular}{|l|l|c|c|}
\hline \multicolumn{5}{|c|}{ Table 1. Basic characteristics of research subjects } \\
\hline Basic characteristics & Median (min-max) & N & $(\%)$ \\
\hline Age (years) & $66(60-87)$ & & \\
\hline Gender & & & \\
\hline Man & & 27 & $(51,92)$ \\
\hline Woman & & 25 & $(48,08)$ \\
\hline Degree of weight & & & \\
\hline Sepsis & & 14 & $(26,92)$ \\
\hline Severe sepsis & & 25 & $(48,08)$ \\
\hline Septic shock & & 13 & $(25)$ \\
\hline Outcome & & & \\
\hline Die & & 27 & $(51,92)$ \\
\hline Life & & 25 & $(48,08)$ \\
\hline Laboratory & & & \\
\hline Haemoglobin $(\mathrm{g} / \mathrm{dl})$ & $11,3(6,3-17,2)$ & & \\
\hline Leukocytes $(103 / \mathrm{ml})$ & $15,26(0,72-32,89)$ & & \\
\hline Platelets $(103 / \mathrm{ml})$ & $150(13-635)$ & & \\
\hline Procalcitonin $(\mathrm{mcg} / \mathrm{dl})$ & $13,42(0,86-100)$ & & \\
\hline
\end{tabular}

The subjects of this study were 52 people who met the inclusion and exclusion criteria. The basic characteristics of research subjects are listed in table 1 . Based on table 1 regarding the characteristics of research subjects. The median value of the age of the subjects was 66 (60-87) years with the most male subjects $51.92 \%$. The diagnosis of severe sepsis was $48.08 \%$, followed by $29.62 \%$ sepsis and $25 \%$ septic shock. Subjects died as many as 27 subjects $(51.92 \%)$. Hemoglobin level $11.3 \mathrm{~g} / \mathrm{dl}$; leukocytes $\quad 15.26 .103 / \mathrm{ml}$; platelets $150.103 / \mathrm{ml}$ and procalcitonin value 12.42 $\mathrm{mcg} / \mathrm{dl}$.

To determine the value of procalcitonin which is used as a predictor of sepsis death in elderly patients, a cut of point is determined through the Receiver of Curve (ROC). Figure 1 shows the ROC of procalcitonin which is used as a predictor of sepsis mortality in elderly patients.

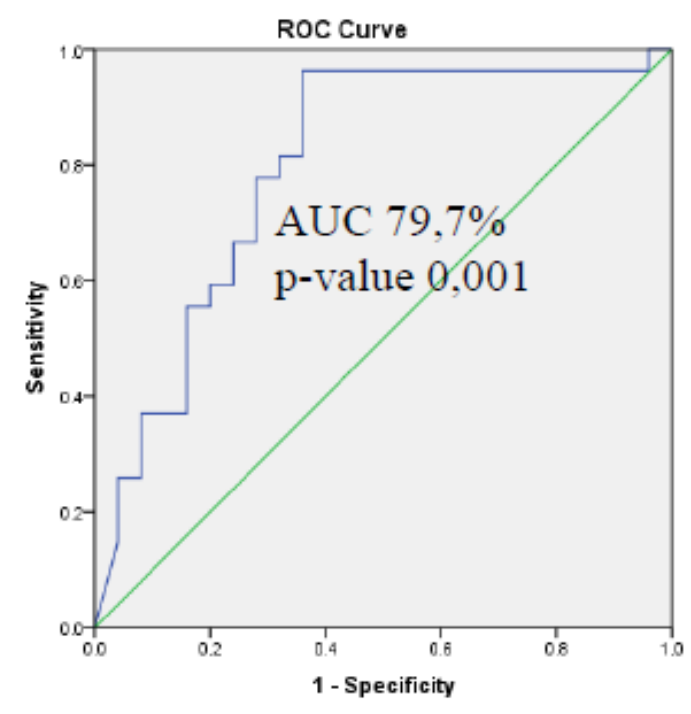

Diagonal segments are praduced by ties

Figure 1. Receiver of curve procalcitonin value as a predictor of septic mortality in elderly patients

In Figure 1, the ROC curve of procalcitonin, shows that procalcitonin has a good predictor value of septic mortality in elderly patients because the curve is far from the $50 \%$ line. The AUC value obtained from the ROC method is $79.7 \%$, the $\mathrm{p}$ value is 0.001. Statistically, the AUC value of $79.7 \%$ is moderate. From the curve above, it can be concluded that procalcitonin can be used as a predictor of sepsis mortality in elderly patients with a level of confidence of $79.7 \%$ significantly. To determine the appropriate procalcitonin value used in order to obtain sensitivity and specificity as well as a good predictive value, it is continued to determine the intersection 
point of the sensitivity and specificity curve. From the figure, the sensitivity and specificity cut point is found at number 25 with a procalcitonin value of $12.67 \mathrm{mcg} / \mathrm{dl}$.

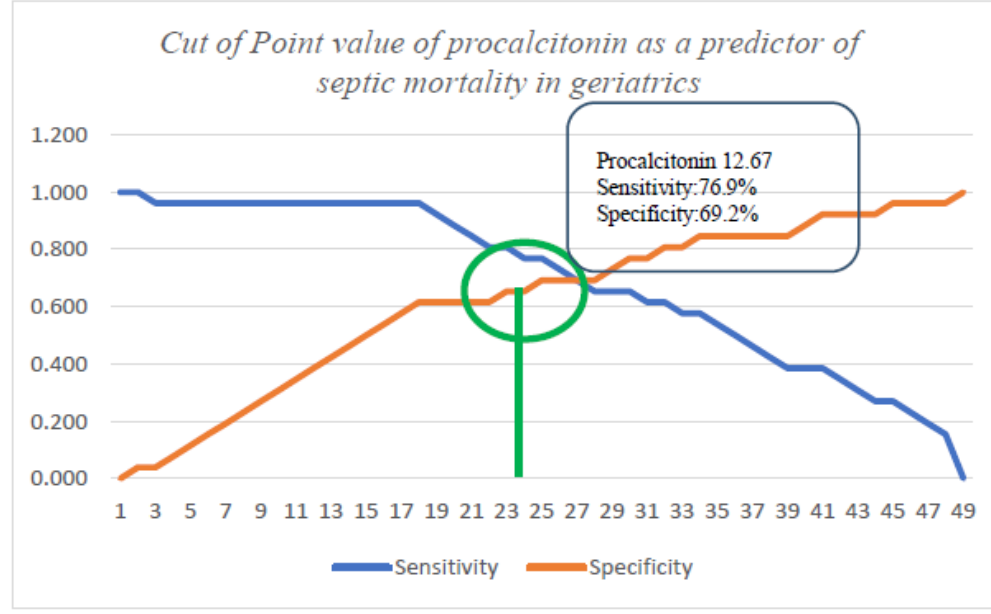

Based on the picture above, the cut point value of procalcitonin is $12.67 \mathrm{mcg} / \mathrm{dl}$. To determine the relationship between the value of procalcitonin as a predictor of sepsis mortality in elderly patients, a chisquare test was performed. The following table 2 shows the results of the chi-square test.

\begin{tabular}{|c|c|c|c|c|c|c|}
\hline \multirow[t]{3}{*}{ Procalcitonin } & \multicolumn{4}{|c|}{ Outcome } & \multirow[t]{3}{*}{$\mathrm{p}$-value } & \multirow[t]{3}{*}{ RR 95\% (min-maks) } \\
\hline & \multicolumn{2}{|c|}{ Death } & \multicolumn{2}{|c|}{ Recover } & & \\
\hline & $\mathbf{N}$ & $\%$ & $\mathbf{N}$ & $\%$ & & \\
\hline$\geq 12,67$ & 21 & 75 & 7 & 25 & 0,001 & $3(1,453-6,196)$ \\
\hline$<12,67$ & 6 & 25 & 18 & 75 & & \\
\hline Total & 27 & 51,92 & 25 & 48,08 & & \\
\hline
\end{tabular}

Based on Table 2, elderly sepsis patients on admission to hospital with procalcitonin levels $>12.67 \mathrm{mcg} / \mathrm{dl}$ died 21 (75\%) patients while elderly patients with procalcitonin levels $<12.67 \mathrm{mcg} / \mathrm{dl}$ died 6 (25\%) patients. The chi-square test got a $\mathrm{p}$ value of 0.001 (RR 3 CI 95\% 1.453-6.196). It can be concluded that septic patients in the elderly with procalcitonin levels $>12.67$ $\mathrm{mcg} / \mathrm{dl}$ upon admission to the hospital will be predicted to die 3 times compared to septic patients in the elderly with procalcitonin levels $<12.67 \mathrm{mcg} / \mathrm{dl}$.

\section{DISCUSSION}

This study was to determine the value of procalcitonin as a predictor of mortality in sepsis patients in elderly patients. The results showed that the procalcitonin value can be a predictor of mortality in elderly patients with a diagnosis of sepsis. Procalcitonin (PCT), a precursor of the hormone calcitonin, is a serological marker of bacterial infection that is being increasingly studied. Most of these studies were carried out in developed countries which have a different spectrum of infectious diseases from developing countries such as Indonesia. ${ }^{[11]}$ Procalcitonin is a 116 amino acid peptide with a size of approximately $14.5 \mathrm{kDa}$ and belongs to the calcitonin peptide superfamily. Procalcitonin has 3 parts, namely the amino terminal region of procalcitonin, immature calcitonin, and calcitonin carboxyl-terminus peptide-1 (CCP-1, also known as catacalcine). ${ }^{[12]}$

Procalcitonin levels in the blood will rise 3 to 6 hours after infection. In other literature, procalcitonin synthesis can be detected in blood serum within 4 hours. Procalcitonin levels will peak within 12 to 48 hours and will decrease within 48 to 72 hours. In neonates, procalcitonin levels will 
increase physiologically and will decrease in the first few days after birth if no infection is found. ${ }^{[12]}$

A meta-analysis showed that procalcitonin levels were more sensitive (88\% [95\% CI 80-93\%] versus $75 \%$ [95\% CI $62-84 \%])$ and more specific $(81 \%$ [95\% CI 67-90\%] than $67 \%$ [95\% CI 56-77\%]) than CRP levels in differentiating bacterial infection and other causes of inflammation. $^{[13]}$ A 2006 meta-analysis involving 49 studies and 3,943 patients showed that procalcitonin is a diagnostic marker for sepsis and is superior to CRP. ${ }^{[14]}$ Contrasting results were obtained in a 2007 meta-analysis, which included 18 studies and 2097 subjects, stating that the diagnostic performance of procalcitonin is still low with sensitivity and specificity values of $71 \%(95 \%$ CI $67-76 \%)$ and an area under the curve of $0 . .78(95 \%$ CI $0.73-$ $0.83) .{ }^{[7]}$

The cut-off of procalcitonin is an indicator in determining the risk of developing sepsis and giving antibiotics. Under normal conditions, procalcitonin levels in the blood $<1 \mathrm{ng} / \mathrm{ml}$, based on other studies, normal levels of procalcitonin in healthy individuals who were not infected were $0.033 \pm 0.003 \mathrm{ng} / \mathrm{ml}$. Procalcitonin levels in the blood will not show a significant increase if there is only systemic inflammation. The cut-off value based on this can be used to differentiate between sepsis, severe sepsis, septic shock, and nonseptic. These criteria can be seen in the ACCP/SCCM criteria. ${ }^{[12]}$ In this study, the cut of procalcitonin as a predictor of mortality in elderly sepsis patients was higher at $12.67 \mathrm{mcg} / \mathrm{dl}$. The level of 12.67 is indeed high compared to the criteria for sepsis, namely levels $>2 \mathrm{mcg} / \mathrm{dl}$.

Arif et al in his study found that the cut off of procalcitonin levels in determining the severity of sepsis was 2.89 with a sensitivity of $98.2 \%$ and a specificity of $75 \% .^{[15]}$ This value is better than the neutrophil lymphocyte ratio to determine the severity of sepsis. A retrospective cohort study in 2014 showed that in 55 critically ill patients studied, the best cut-off value of procalcitonin for the diagnosis of sepsis was $1.1 \mathrm{ng} / \mathrm{ml}$ (82\% sensitivity, $68 \%$ specificity, and $71 \%$ negative predictive value). ${ }^{[14]}$ In the ProHOSP study, procalcitonin levels can be used as an indicator in determining antibiotic administration in cases of suspected infection. The categorization used is very likely non-bacterial infection $(<0.1$ $\mathrm{ng} / \mathrm{ml})$, infection may not be bacterial (0.1$0.25 \mathrm{ng} / \mathrm{ml}$ ), infection may be bacterial (> $0.25-0.5 \mathrm{ng} / \mathrm{ml}$ ), and infection is very likely bacterial $(>0.5 \mathrm{ng} / \mathrm{ml})$. In non-bacterial infections, antibiotics are not recommended. Appropriate antibiotic therapy will reduce procalcitonin levels and vice versa. ${ }^{[12]}$

\section{CONCLUSION}

Procalcitonin is associated with mortality in elderly septic patients.

\section{Acknowledgement: None}

\section{Conflict of Interest: None}

\section{Source of Funding: None}

\section{Ethical Approval: Approved}

\section{REFERENCES}

1. Lakshmikanth CL, Jacob SP, Chaithra VH, de Castro-Faria-Neto HC, Marathe GK. Sepsis: in search of cure. Inflamm Res, 2016.

2. Dellinger P, Levy MM, Carlet JM, Bion JB, Parker MM, Jaeschke R, Reinhart, K. et al. Surviving Sepsis Campaign: International guidelines for management of severe sepsis and septic shock: International Surviving Sepsis Campaign Guidelines Committee. 2013.

3. Angus DC, Linde-Zwirble WT, Lidicker J, et al. Epidemiology of severe sepsis in the United States: analysis of incidence, outcome, and associated costs of care. Crit Care Med 2001; 29:1303-1310

4. Hermawan AG. 2014. Sepsis dalam Buku Ajar Ilmu Penyakit Dalam Jilid I edisi VI. Interna Publishing. Jakarta.

5. Nasa P, Juneja D, Singh O. Severe sepsis and septic shock in the elderly: An 
overview. World J Crit Care Med2012 February 4; 1(1): 23-30

6. Lemay AC, Anzueto A, Restrepo MI, Mortensen EM. Predictors of LOng-Term Mortality after Severe Sepsis in the Elderly. Am J Med Sci. 2014 April ; 347(4): 282288. doi:10.1097/MAJ.0b013e318295a147

7. Tang BMP, Eslick GD, Craig JC, McLean AS. 2007. Accuracy of Procalcitonin for Sepsis Diagnosis in Critically Ill Patients: Systematic Review and Meta-analysis. Lancet Infect Dis 2007; 7:210-17

8. Riedel S, Melendez JH, Janet AT, Zenilman JM. 2011. Procalcitonin as a Marker for the Detection of Bacteremia and Sepsis in the Emergency Department. American Journal of Clinical Pathology 2011;135:182-189.

9. Schuetz P, Albrich W, Mueller B. Procalcitonin for diagnosis of infection and guide to antibiotic decisions: past, present and future. BMC Medicine 2011, 9:107.

10. Djitmau, ASL. Perbedaan sensitivitas dan spesifisitas DNI dan prokalsitonin dalam menegakkan diagnosis sepsis. Tesis. Fakultas Kedokteran UGM. 2016. Yogyakarta.

11. Husada D, Adnyana IGNT, Setyoningrum RA, Saharso D, Ismoedijanto. Akurasi Diagnostik Prokalsitonin Sebagai Petanda Serologis untuk Membedakan Infeksi
Bakteri dan Infeksi Virus pada Anak. Sari Pediatri, Vol. 13, No. 5, Februari 2012

12. Saraswati PFD. Faktor yang Berhubungan dengan Hasil Tes Prokalsitonin pada Sepsis. 2012. Fakultas Kedokteran Universitas Diponegoro.

13. Simon L, Gauvin F, Amre DK, Saint-Louis P, Lacroix J. Serum Procalcitonin and CReactive Protein Levels as Markers of Bacterial Infection: A Systematic Review and Meta-analysis. CID 2004:39.

14. Uzzan B, Cohen R, Nicolas P, Cucherat M, Perret GY. Procalcitonin as a Diagnostic Test for Sepsis in Critically Ill Adults and After Surgery or Trauma: A Systematic Review and Meta-analysis. Critical Care Medicine 2006 Vol. 34, No. 7

15. Arif SK, Rukka ABS, Wahyuni S. Comparison of Neutrophils-lymphocytes Ratio and Procalcitonin Parameters in Sepsis Patient Treated in Intensive Care Unit Dr. Wahidin Hospital, Makassar, Indonesia. J. Med. Sci., 2017, 17 (1): 17-21

How to cite this article: Anita Rosari Dalimunthe, I Dewa Putu Pramantara, Probo Suseno. Association of procalcitonin values with mortality of elderly sepsis patients. International Journal of Research and Review. 2022; 9(2): 17-22. DOI: https://doi.org/10. 52403/ijrr.20220204 